\title{
Knowledge About Upcycling and Attitude Towards Purchasing Upcycled Products Among Students in Khammam (19-24 years) - A Cross Sectional Study
}

\author{
K. Sai Hima Thriveni ${ }^{1 *}$, K. V. N. R. Pratap ${ }^{2}$, T. Madhavi Padma ${ }^{3}$, V. Shiva Kalyan ${ }^{4}$, P. Srikanth ${ }^{5}$ \\ ${ }^{l}$ BDS Student, Department of Public Health Dentistry, Mamata Dental College, Khammam, India \\ ${ }^{2}$ Professor \& HoD, Department of Public Health Dentistry, Mamata Dental College, Khammam, India \\ ${ }^{3}$ Professor, Department of Public Health Dentistry, Mamata Dental College, Khammam, India \\ ${ }^{4}$ Reader, Department of Public Health Dentistry, Mamata Dental College, Khammam, India \\ ${ }^{5}$ Lecturer, Department of Public Health Dentistry, Mamata Dental College, Khammam, India \\ *Corresponding author: thrivenikarnati@gmail.com
}

\begin{abstract}
Background: Growing fashion trends is driving to utilize more natural resources and this practice of utilizing abundant amounts will however deplete them. The moto of this study is to know the knowledge about upcycling among under graduates and their perspective towards purchasing upcycled products.

Method: A Questionnaire based survey was organized among dental students of Mamata dental college, Telangana. This is prepared to know the knowledge about upcycling and their attitude to purchase upcycled products.

Results:

The results have showed that majority of dental students have little knowledge about upcycling, ignorant towards purchasing the upcycled goods, the concept in daily life.

Conclusion:

From the results of survey, it is necessary to create the awareness among students about upcycling through various competitions, programs to change their thinking about sustainability of upcycled products.
\end{abstract}

Keywords: Economic, Innovative ideas, Self-employment, Stress buster, Resource consumption, Upcycling.

\section{Introduction}

Today, in advancing world along with new innovations we humans are mutilating Mother Nature. With changing trends across the world we want to be funky from tip to toe with brand new products, which often sink the natural resources. To decrease this enormous consumption there comes a most valuable strategy - upcycling which means "Waste with lesser value is converted into a new product with greater value." Upcycling is a unique subset of recycling which is defined as "recovery of useful materials such as paper, glass, plastics, metals, construction \& demolition, organics from waste stream and transformation of that material to make new products, resulting in a reduction in the amount of virgin raw materials needed to meet consumer demand." [5] In contrast to reusing/recycling, upcycling uses existing materials to improve upon original ones [2]. Murray (2002) states that design for upcycling about not merely conserving the resources that went into the production of particular materials, but also adding to the value embodied in them, by application of knowledge in course of their recirculation [2]. Usually upcycling stops insertion of fresh resources to the world that is already saturated by tangible goods [1]. Many people speak about Eco-fashion but less fascinated to adopt that concept in to their lives. They might suspect the products sustainability which leads to attitude-purchase gap. This gap may be filled by helping the people to gain knowledge about upcycled products through various competitions/workshops/campaigns. Explaining its importance, various advantages might increase the people's passion towards the upcycled products, thus promoting upcycling concepts indirectly propagating the concept of greener earth. The objectives of my study are to assess the knowledge about upcycling and attitude regarding purchasing upcycled products and concept implementation in daily life among students.

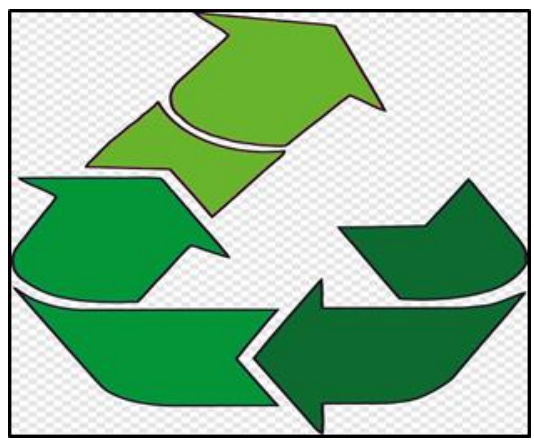

Fig. 1. Upcycling logo 


\section{Methodology}

Permission was taken from Head of the department of public health dentistry. A Cross Sectional questionnaire-based study was conducted among students of Mamata dental college, Khammam. After questionnaire framed it was distributed to approximately 30 students for pilot study. Survey was conducted among 200 dental student's personal data was included in the questionnaire. All interns, third year and fourth year students who were present during the day of survey included. A student who was absent during the day of survey were excluded. Responses of individuals were entered into Microsoft excel sheet and analysis was performed by SPSS 25 . Chi square test was used to detect association among categorized values. The level of significance was set at $p<0.05$.

\section{Results}

With an intention to uproot the relevant information from data collected the interpretation was carried out. The figures were first revised, observed, tabulated. The purpose of study is to focus on knowledge about upcycling among dental students and their attitudes to purchase them.

Table 1

Categorization of participants based on gender

\begin{tabular}{|l|l|}
\hline Gender & Percentage \\
\hline FEMALE & $84.5 \%$ \\
\hline MALE & $15.5 \%$ \\
\hline
\end{tabular}

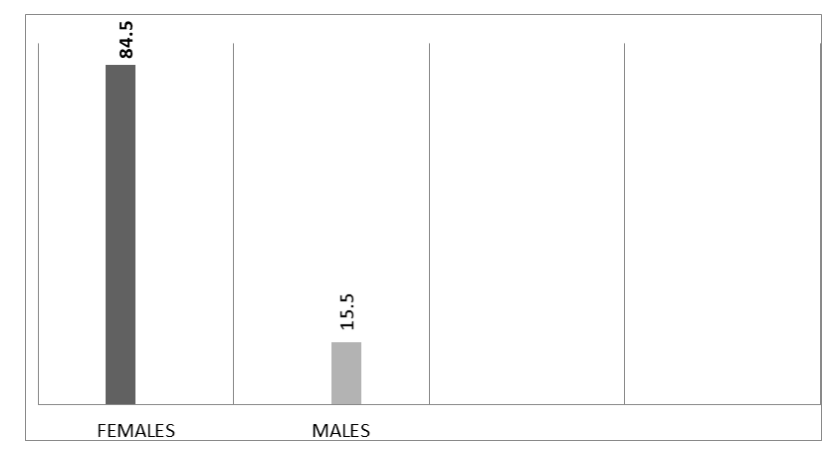

From the above table it is clear that $84.5 \%$ participants are females while $15.5 \%$ are males.

Table 2

Q: What is meant by term upcycling?

\begin{tabular}{|c|c|}
\hline Options & Percentage \\
\hline Climbing of mountains & $6.5 \%$ \\
\hline $\begin{array}{l}\text { Transforming waste of lesser value into } \\
\text { new materials of greater value }\end{array}$ & $63.5 \%$ \\
\hline Waste disposal & $8 \%$ \\
\hline Any brand name & $1 \%$ \\
\hline Don't know & $21 \%$ \\
\hline
\end{tabular}

From the above data majority of participants i.e. $63 \%$ have answered upcycling means transforming waste of lesser value to new materials of greater value, $21 \%$ individuals don't know about upcycling.
Table 3

Q: Do you find upcycled products sustainable?

\begin{tabular}{|l|r|}
\hline \multicolumn{1}{|c|}{ Options } & Percentage \\
\hline Yes & $43 \%$ \\
\hline No & $12 \%$ \\
\hline Don't know & $44.5 \%$ \\
\hline
\end{tabular}

From the above table $44.5 \%$ people answered don't know, $43 \%$ individuals found upcycled products sustainable.

Table 4

Q. Who used the term upcycling first?
\begin{tabular}{|l|c|}
\hline \multicolumn{1}{|c|}{ Options } & Percentage \\
\hline REINER PILZ & $12.5 \%$ \\
\hline CARL ANDERSON & $15 \%$ \\
\hline VIRGINIA APGAR & $13 \%$ \\
\hline EMILE BERLINER & $5 \%$ \\
\hline DON'T KNOW & $54.5 \%$ \\
\hline
\end{tabular}

From the above table $54.5 \%$ students don't know who used the term upcycling first.

Table 5

Q. Did you ever applied upcycling concept in daily life?

\begin{tabular}{|c|c|}
\hline Options & Percentage \\
\hline Yes & $42 \%$ \\
\hline No & $58 \%$ \\
\hline
\end{tabular}

From the above table it is clear that $58 \%$ individuals have not applied upcycling concept in daily life.
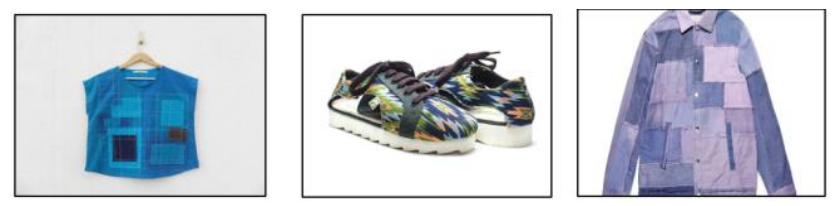

Fig. 2. Upcycled fashion products

\section{Discussion}

This survey was conducted to evaluate the knowledge about upcycling and their attitude to purchase these products. It was organized in Mamata dental college Khammam. This study was dominated by females than males. Interestingly $63.5 \%$ people have answered upcycling means "Transforming waste of lesser value to new materials of higher value" which may convey that higher proportion people may know the concept of upcycling. Knowing about the strategy may promote their interest for ecofriendly products. Miserably $44.5 \%$ proportions don't know whether upcycled products are sustainable or not. This confusion about sustainability might be due to lack of interest to apply the concept or not using product because it is made from waste or not knowing about the concept or might be interesting about products but not interested in purchasing them. Also, majority of people don't know that Reiner Pilz had introduced the term upcycling. Surprisingly 58\% students have not applied the concept of upcycling in their daily life!!! This may be due to lack of time to apply this concept in their daily life. However, this study was limited only to 200 dental 
students, which may be a limitation to my study. Common people may have more knowledge about this concept than dental students.

\section{Conclusion}

Upcycling, a unique concept has several advantages like encouraging new talents, creative ideas, increasing employment, may be a stress buster also requires less finance. However, costs of upcycled goods are high which may not encourage people to buy them. Starts ups like Rimagined, the upcycle co., Green sole are least popularized, collaboration with large firms may gain popularity, acceptance of these products among people. We are taking unhesitating steps towards destruction of earth; but let's together try to take baby steps to save the mother green by introducing novel concepts like upcycling in to our lives.

\section{References}

[1] Park HH. The influence of LOHAS consumption tendency and perceived consumer effectiveness on trust and purchase intention regarding upcycling fashion goods. International Journal of Human Ecology. 2015 Jun;16(1):37-47.

[2] Kushwaha S, Swami C. Upcycling of leather waste to create upcycled products and accessories. Int J Home Sci. 2016;2:187-92.

[3] Karina I. Upcycling Technique for Eco-Fashion Products made by Slum Communities at Cakung, Indonesia: Students' Experience. Pertanika Journal of Social Sciences and Humanities. 2016 Jun 1:155-62.

[4] Park HJ, Lin LM. Exploring attitude-behavior gap in sustainable consumption: Comparison of recycled and upcycled fashion products. Journal of Business Research. 2018 Aug 29.

[5] Flowers J, Rauch C, Wierzbicki A. Teaching upcycling to impact environmental attitudes. Journal of Technology Education. 2018; 30(1):30-45.

[6] Broega AC, Santos MO, Soares BO. Reuse of clean waste from the fashion industry in sustainable design development with a focus on social responsibility. 2016 June 8-10.

[7] Sung K, Sung K. A review on upcycling: Current body of literature, knowledge gaps and a way forward. World Academy of Science, Engineering and Technology. 2015 Apr, 17(4).

[8] Sung K, Cooper T, Kettley S. Individual upcycling practice: Exploring the possible determinants of upcycling based on a literature review. 